\title{
Offspring as Enemy? How Canada's National Magazine Confronted Youth and Youth Culture in the 1960s
}

\section{Jaymie Heilman}

ABSTRACT: The idea of a "generation-gap" is one of the principal features in the mythology of the 1960 s. The construct implies that the response of parents to the social and cultural activism of their teenage baby-boomers, those born in the period 1946-1962, was systematically hostile and decidedly unsympathetic. An examination of the contents of the Canadian periodical Maclean's between the years 1959 and 1973, however, reveals a very different reaction towards youth. Attitudes in the magazine regarding youthculture were generally positive and frequently laudatory, thus calling into question the reality of the generation-gap.

The 1960s are a period defined by symbols. Alongside tiedyed shirts, marijuana, and protest marches, the idea of a fundamental gap between young and old figures prominently. The scenario is an easy one to construct. Canadians faced the horrors of Dieppe and Normandy in the Second World War to secure a better world for the children they had or planned to have. After the war, families moved to the suburbs to provide a safe and loving environment for growing-up and they lavished their kids with love and material wealth. When those children reached adolescence in the 1960s, however, they appeared to reject everything that their parents embodied. Casual sex replaced commitment and marriage; affluence was rejected as immoral; American radical Jerry Rubin told teenagers to "Kill Your Parents";' and the slogan "never trust anyone over thirty" was repeated constantly. It was a tremendous affront and parents reacted with equal animosity. 
In retrospect, it is very difficult to distinguish the mythology from the reality. An attempt to assess the reality of this "generation-gap" figures as a worthy topic for study not only because of the gap's prominence in the lore of the $1960 \mathrm{~s}$, but because of its importance to the way that the youth of this period perceived themselves. In general, the people born in the 1946 to 1962 "baby-boom" have always had a strong sense of their own difference. ${ }^{2}$ Babyboomers were more numerous, affluent, and self-aware than any previous generation ${ }^{3}$ and as they entered their late teens and twenties in the mid 1960s, many felt themselves divorced from the society which had created them. The public protest, drugs, and unkempt hair which characterized the decade marked some of the ways in which these youth asserted their uniqueness and expressed their dissatisfaction with contemporary society. In this context, the conflict of generations was not simply another "gap" to add to a growing list which already included the "missilegap" and the "education-gap." Instead, the generationgap was central to baby-boomers' own sense of revolutionary difference; if their elders had really understood and identified with them, that would have diminished the scale of their uniqueness. The notion of intergenerational hostility was thus integral to boomers' definition of themselves and the continued prominence of this group in society has made the generation-gap a staple in today's popular recollections of the $1960 \mathrm{~s}^{5}$

With the nature of generational relations being so tied up in the imagery of the 1960s and in boomers' perceptions of themselves, it is important to step back from the mythology and attempt to understand and assess what the older English-Canadian generation really thought of youth in the 1960s. To that end, I have turned to the contents of Maclean's magazine between 1959 and 1973. In the spate of articles published on youth and their lifestyles, the "evil triumvirate" of sex, drugs, and rock-and-roll (with some 
Eastern spiritualism added to the mix) was not unilaterally dismissed as degenerate, and examinations of university life showed above all else a strong concern for the welfare of youth. Youth radicals were characterized as a fairly honorable group, and while the hippies were a strange and occasionally disconcerting phenomenon, the considerations were typically sympathetic. Those teenagers outside the radical and hippie circles were characterized as a wholesome, if tremendously unrepresentative, group. In the end, the fabled generation-gap, itself given only sparse attention by Maclean's, was neither as virulent nor as absolute within the pages of this magazine as the popular memory of the 1960s suggests.

Linked to this question of reality versus image is the role accredited to the media in the 1960s. In his influential book The Making of a Counter Culture, Theodore Roszak charged that the "fun-house mirror of the media" had fundamentally altered the beatnik and hippie movements by exposing them to the attention of countless philosophically shallow youth who proceeded to inundate and overwhelm the movements. ${ }^{6}$ Assessing the degree to which the 1960s were a construct of the media is an investigation beyond the scope of this paper, but it is a reservation that should be kept in mind. The media has also been blamed for the "decacide" of the $1960 \mathrm{~s}$; 7 it was accused of engaging in a saturation coverage of youth which created a climate of opinion fundamentally hostile towards the young. ${ }^{8}$ This destructive role is more easily evaluated and an effort will be made to determine whether the coverage in Maclean's may have augmented this hostility.

By looking at articles from 1959 to 1973 , I hoped to find responses to both the beginnings and endings of counter-culturalism and radicalism. By choosing Maclean's, I hoped to find one, although by no means the only, representative of both Canadian sentiment and 
Canadian media. With a 1963 circulation rate of 515,000 , Maclean's was certainly not reaching a huge percentage of Canada's 18 million people 9 and even if a magazine was purchased, it may well have sat unread, decorating a living-room coffee table. Similarly, popular American magazines like Look, Life, and the Canadian edition of Time probably had just as many Canadian readers as Maclean's, if not more. Further, there is the issue of bias. Critics ranging from former American vice-president Spiro Agnew to media mogul Conrad Black have reproached the media for its left-wing slant. ${ }^{10}$ As is true today, Canadian journalists in the 1960 s tended to be urban, affluent, educated, and liberal in their outlook and the perspectives offered in Maclean's admittedly did not reflect rural, working-class, or conservative values. Likewise, Toronto was quite clearly the core of Canada's publishing industry in the $1960 \mathrm{~s}^{11}$ and Maclean's subsequently reflected that Eastern outlook. These accusations of bias are augmented by the fact that many of those writing in Maclean's formed part of an exclusive Canadian media elite. Names like Peter Gzowski and Barbara Frum are immediately recognizable given their consistently high profile in the press, radio, and television. Such omnipresence suggests a limited diversity of opinion in the mainstream Canadian media and in Maclean's.

These criticisms, however, must be tempered by the fact that Maclean's was, and remains, a mass magazine, whose primary purpose was to make money. Popular magazines derive the bulk of their revenue from advertisements and thus even if there is some lurking liberal agenda among journalists, one has to remember that advertisers are not likely to commit money to something which they feel has no appeal for the public. ${ }^{12}$ As such, contents are likely to reflect public opinion, or at least attempt to do so, rather than represent an effort at manipulation dreadfully out of touch with readers' views. 
This need to appeal to readers is shown by the fact that in 1969 Maclean's altered its format, shrinking its page size and running more articles in a single sequence of pages to give it a design much closer to its American competitor Time. ${ }^{13}$ The editors at Maclean's obviously had the magazine's popularity in mind.

Further, in defending Maclean's as an important reflection of common Canadian attitudes, one must consider the magazine's position within the Canadian media. A variety of Canadian periodicals were examined, but the focus is on Maclean's, principally because of the accuracy of its self-proclaimed status as "Canada's National Magazine." Its closest competitor, Saturday Night, was selling only 76,000 copies a year and while women's magazines like Chatelaine and Liberty outsold Maclean 's, ${ }^{14}$ their contents were generally limited to recipes, fashion, and advertisements. While Maclean's had a decidedly liberal perspective, it was in the political middle-ground when compared to magazines like today's Alberta Report or Canadian Forum which appeal only to a specific political bent. Similarly, while it was Torontobiased, Maclean's still represented a more national outlook than explicitly regional magazines like Western Living.

Most importantly, Maclean's popularity grew over the decade. By 1970 , its circulation stood at $749,000,{ }^{15}$ up over 200,000 in less than ten years. Actual readership was likely even higher given the fact that when it came in to a Canadian home, Maclean's was probably read by several members of the family. Similarly, one can only imagine how many bored Canadians flipped through the magazine as they were waiting for doctor, dentist, or hair appointments. While the articles appearing in Maclean's could never represent everyone, it is safe to assume that they appealed to at least someone, or else people would not have bought the magazine at all. 
Before beginning the examination of Maclean's contents, a final issue about the magazine's relationship to Canadian society needs to be addressed. In this study, Maclean's magazine is presented as one voice of those English-Canadians who fell on the "Establishment" or parent side of the generation-gap. Such a presentation, however, is limited by the fact that several of the magazine's writers ${ }^{16}$ were themselves too young to be situated on the parent half of the gap. Dismissing the magazine's sympathetic portrayal of youth as little more than the product of having young writers on staff, however, ignores the above mentioned emphasis which a magazine like Maclean's must place on earning money. If the journalism of the younger writers was consistently at odds with the viewpoints of those old enough to have teenage children, Maclean's would likely have lost a tremendous portion of its market and the editors would probably have endeavored to change the tone of the magazine's articles. As neither event occurred, it seems reasonable to suggest that Maclean's can still be offered as one representative of the parent contingent in the conflict of generations.

The teenage sexual revolution of the 1960 s was more a shift of perception than of numbers. Various American studies observed a steady rise in the frequency of premarital sex between the First World War and the 1960s, but it was not until the latter period that people generally regarded sex instead of kissing as a teenage convention. ${ }^{17}$ Even if the change in volume was not dramatic, the sudden sense of difference was, and it alarmed many. In Canada, Simma Holt wrote a book lamenting the collapse of traditional standards of morality among teenagers and offering advice on how parents and communities could fight promiscuity and its "consequent human tragedy."18 Yet despite the appearance of a loud group of young people speaking openly about the value of nudity, free love, and the pleasures of orgies, Maclean's generally opted to stay out of the bedrooms of Canadian youth. 
With regards to sex, it was the Pill, not promiscuity, that drew the most attention. The magazine's response to this revolutionary contraceptive, which like all other birth control remained technically illegal to sell or promote until 1969 , was overwhelmingly positive. In 1964, an editorial advocated the legalization of birth control ${ }^{19}$ and other articles heralded it as a panacea for social ills. One claimed the Pill would bring, "new freedom, less divorce, a lower birth rate, a better educated population, and an end to illegitimacy." 20 Worries about increased premarital sex were subsumed by concerns over side-effects and criticism of the Pill was effectively dismissed by designating it as an effect rather than cause of the sexual revolution. ${ }^{21}$

Abortion was also given similar sympathy, if less attention, with articles like "Meet your Friendly Local Abortionist" which stressed legalized abortion as humane and a preferable alternative to suicide and illegal abortion. ${ }^{22}$ This liberal take on birth control and abortion reflects the results of Canadian Gallup polls in the 1960s and early 1970s in which increasingly positive attitudes towards both were recorded. ${ }^{23}$ Additionally, while North America had enjoyed a benign "baby-boom," concurrent increases in birth rates in the Third World were a menacing "populationexplosion," and throughout the 1950s Canadians had been warned that such growth in underdeveloped countries represented a greater threat to humanity than nuclear war. ${ }^{24}$ The Pill was thus likely seen by many as a welcome solution. As of 1970, however, most Canadians were still saying premarital sex was wrong and it is clear that birthcontrol could easily have been denounced as an agent of immorality among youth. ${ }^{25}$

For Maclean's, until 1966 it seemed that the most immoral activity going on between teenagers was goingsteady. In 1959, this dating practice was labeled an epidemic and condemned not only for promoting passivity, conformity, and psychological suffering, but also for the 
constant risk that "something might happen."26 Similarly, when Mordecai Richler wrote of "Making it with the Chicks,"27 his first girlfriend's refusal to kiss him was about as steamy as it got. The first suggestion that sex was becoming a somewhat more critical topic for youth appeared with Pierre Berton's 1963 suggestion that he would prefer his daughters to have sex rather than feel guilt-ridden and frustrated, and that he expected his son to lose his virginity prior to marriage. Owing to the vehemence of readers' responses which included "shocking", “diabolical", "degenerate", and "cancel my subscription", Berton's column was pulled from the magazine and, likely for the same reason, the subject was not broached again for three years. ${ }^{28}$

When the issue of pre-marital sex was finally tackled, rather than being denounced as wrong, it was endorsed by a radical theologian as being more moral than the older standard which was fraught with lies and exploitation. Even more striking, the rebuttal that appeared below it did not challenge the minister's words; instead it complained about the fact that those words were coming from a clergyman. When promiscuity was eventually condemned in 1971 , the complaint was that such behavior could do emotional damage, not that it was morally wrong. ${ }^{29}$

Maclean's failure to denounce the Pill; its slowness in leaving the sexual confines of the 1950s; and the sparse, ambivalent nature of its treatment of youth and sex illustrate that this magazine hardly engaged in the kind of exploitative and exaggerated coverage of which the media has been accused. The Canadians reading Maclean's were by no means exposed to hostile rantings about the younger generation's sexual immorality, as suggested by the memory of the generation-gap.

This kind of limited approach towards sex also ignored some important changes that were clearly underway. If anything, the sexual revolution of the period was a 
revolution for women. Given the resigned "boys will be boys" attitude that had prevailed, the issue of pre-marital virginity was predominantly a girl's concern. It was girls who lost their worth when they lost their virginity and it was girls who were expected to exercise self-restraint. ${ }^{30}$ The rejection of these stigmas that began in the $1960 \mathrm{~s}$ thus entailed major change for men but dramatic change for women. In youth culture, women began to proposition men $^{31}$ and female icons like Janis Joplin spoke openly of enjoying sex outside marriage. In the pages of Maclean 's, however, there was just no such thing as a woman on the make. In articles like "A Little Girl in a Big, Big Town" and "The Unchaperoned Girl's Guide to Europe," Canadians were presented with images of pure young women surrounded by vice, having to combat married men and French bachelors anxious to deflower them. When asked about love in one 1967 interview, the girl stressed caring and giving while the boy just kept repeating the word "sex." It was men, not women, with whom Adrienne Clarkson chose to discuss love and sex and Maclean's fashion pages urged women to go "Back to the Virginal Look for Spring" and to engage in "The New Modesty." 32 Clearly, sex and sexuality remained a man's domain.

Similarly ignored were the earliest precursors of the movement for women's equality. The role of groups like the Vancouver Women's Caucus and the Voice of Women in pushing for the legalization of birth control and abortion was overlooked and the more subtle repercussions of "Free Love", such as the fact that women often had to have sex they did not want just to prove they were liberal, were missed entirely.

Reading Maclean's, one would never have known that nudity became a trend among some youth, much less that it was celebrated to the extent that an American babyboomer heralded himself as the "nude candidate for president" in $19688^{34}$ Similarly, while the young man 
Adrienne Clarkson interviewed stated his principled opposition to monogamy, there was never any suggestion that this belief about sex had any wider base of support, which it in fact did. With these portrayals and omissions, Maclean's offered a perspective on the sexual revolution that was more naive and limited than it was angry or judgemental.

Whatever the generation-gap was, drugs were at the center of it. In 1962, the RCMP reported 20 cases involving marijuana. By 1969 the number stood at 4,215 cases, and within one year that number had doubled. ${ }^{36}$ In 1961, the number of young adults (16-24) charged under the Narcotics Act was 156; by 1973, under the new classification of juvenile (under 18), there were 2,221 charges. The response of the "Establishment" was not particularly understanding. In 1971, a Montreal sessions judge recommended the restoration of the death penalty to deal with drug traffickers. The New York Times blamed marijuana for "Vagabondage, dependency, and psychiatric disability" and in 1971, 77 per cent of Canadians labeled marijuana a serious problem in high schools. ${ }^{38}$ It is against this atmosphere that Maclean's treatment of drugs must be assessed.

Neither the onslaught of marijuana and other illegal drugs nor the passionate reaction against them were without precursors. As early as 1959, Maclean's ran an article entitled "Fighting the Teenage Drug Habit" and in 1961 there was concern not only over the violent effects of "goofballs", mixtures of barbiturates and amphetamines, but also over the bold assertion of a dealer that he had never encountered a teenager unwilling to try the drug.

Marijuana made its grand appearance in 1964 and Maclean's was by no means welcoming. In one article, doctors who recommended treatment rather than repression were dismissed as idealists, while police who warned of an inexorable link between pot and heroin, pot 
and the Mafia, pot and prostitution, and pot and drug dependence, were labeled realists. On the adjoining page the recollections of a former marijuana dealer appeared; he was assessed as disturbing not only because of his glib attitude but also because of his college education and church background. ${ }^{40}$ Maclean's thus betrayed what was probably a common fear: a wholesome appearance and background were no longer guarantors of morality.

The magazine's attitude did not soften with time. While the article "Some of the Best People Smoke Pot" sounds forgiving, the implication was that the problem was growing more widespread and the link to harder drugs (even injecting meat tenderizer!) was again stressed. In 1970, Maclean's conjecturally blamed the Charles Manson murders on marijuana and 1973's "Keep off the Grass" warned of dangers like memory loss and the possibility of a future "chemophilic society" in which everyone would be perpetually high.

Was Maclean's overreacting? That is certain. The fundamental link between pot and harder drugs never emerged; Canadian heroin use increased but not nearly as dramatically as marijuana and there was even a clear opposition to hard drugs within the counter-cultural movement. ${ }^{42}$ Similarly, it is clear that countless teenagers in Canada and the United States used marijuana without ever broaching the limits of more serious crimes.

These are, however, criticisms capitalizing on the benefit of hindsight. What is more important is that Maclean's confirmed and augmented fears probably already present within Canadians' minds. Saturday Night was decidedly more liberal towards marijuana, running several editorials in favor of legalization. It too, however, repeatedly linked pot to heroin, crime, and death ${ }^{44}$ and with the rise in usage being so sudden and explosive, it is not realistic to expect that these magazines would have reacted any more favorably. This was clearly one aspect of youth culture that could not be accepted. 
Paradoxically, hallucinogenic drugs like LSD were not the subject of similar fears. Published in 1970 and selling over one million copies, American singer Pat Boone's book A New Song warned that,

One trip on LSD may affect four generations of children born afterwards. And, of course, we know that some children born to LSD users have had exposed spines, two heads, and other gruesome physical deformities. $^{45}$

With such obvious inflammatory discussion of hallucinogenic drugs being fairly common, it is surprising that Maclean's analysis never really left the realm of curiosity. In 1961 Maclean's printed a series of drawings created before and after artists consumed psilocybin, a Mexican mushroom. While the "after" drawings were all disturbing, the conclusion was simply that the work of conservative artists had been made more modern. ${ }^{46} \mathrm{By}$ 1964, when hallucinogens had already found their way into the counter-culture and when the magazine was flatly denouncing marijuana, LSD was enthusiastically endorsed as a possible solution to mental illness, alcoholism, and even crime. Further, one author quoted Dr. Timothy Leary, one of the foremost spokesmen of the youth drug scene, who argued hallucinogens "can make the average person happier, wiser, kinder, and more creative." "I7 In 1966, the magazine again stressed the drug's clinical values in the article "How LSD saved my Marriage." This willingness to endorse LSD probably owes much to the fact that Maclean's journalist Sidney Katz had himself tried LSD in 1953 as part of a professional psychology experiment and suffered no long-term effects.

This kind of fascination with LSD was not unique; Saturday Night ran a 1966 article in its religion section assessing the potential use of LSD for religious 
enlightenment. ${ }^{48}$ What is striking, however, is that the intrigue never gave way to concern. Nothing even close to Boone's statements, Chatelaine's worried conclusion that LSD reduces brains to rubbish, ${ }^{49}$ or even Maclean's own assessments of marijuana was ever written. LSD was just not given serious attention as a factor in youth culture and thus the magazine did not reflect any major panic over the drug.

The most inflammatory pieces Maclean's wrote on drugs were two articles on how to determine whether or not your child was on drugs. ${ }^{50}$ Both pieces singled out tell-tale signs like mood-swings, irritability and changes in appearance as the best way to spot drug use. With these signals being the mainstays of probably every teenager undergoing the trauma of puberty, one cannot help but imagine that every nervous Canadian parent who saw these articles would have been convinced that they were sheltering an addict.

All of Maclean's writers were from different age groups but none grew up at a time when drug-use was a common problem. The newness of the phenomenon combined with the fact that usage was escalating so explosively probably explains why the occasional dangers of drugs were stressed rather than minimized. The magazine recounted tales of drug-induced stabbings and it was made clear that this, unlike Vietnam, was something Canadians could not dismiss as an American problem. Given this attitude, it is understandable that the magazine did not explore the justifications teenagers offered for their drug use, ranging from "cultural detoxification" to heightened intimacy, but that failure does show a simplification in its coverage. Worse, there was no attempt to quantify the situation. Arrests for drug use had unquestionably risen dramatically, but 2,221 charges for juveniles in a population of over two million teenagers between 15 and 19 years old suggests that drugs were clearly a minority experiment. ${ }^{53}$ Reading. 
Maclean's, however, leaves the impression of a far more serious problem and Canadians were most likely misled.

For an older generation that saw Frank Sinatra's sentimental and subdued songs as the center of their own musical rebellion, one would expect that music characterized by blaring electric guitars and often unintelligible lyrics would have been dismissed as little more than noise. In fact, rock-and-roll won far more praise than it did criticism in this magazine. Because the early 1960s favored songs as harmless and banal as "Big Girls Don't Cry" and "The Monster Mash," it is not particularly surprising that rock was ignored by Maclean's until 1964 when commentary on the Beatles' visit to Canada appeared. The icons were assessed as a menace, having caused a riot among silly teenage girls, and not particularly worthy of the admiration given their cockiness, jeering, and leering. ${ }^{54}$ Subsequent considerations, however, brightened considerably.

Unlike the New York Post which labeled musician Bob Dylan "a walking slum," Maclean's called him highly influential in the rock phenomenon which in turn was described as "the most vital and exciting art form in America." The author, Peter Gzowski, stated he was wrong to have dismissed rock as "too loud, too boorish, too dull" and that instead the music was poetic, moving, and relevant. Admittedly, Gzowski was young at the time, a member not of the baby-boom but of the similarly rebellious beatnik generation, and it is possible that many of his coworkers pointedly disagreed. They did not, however, publish any articles. The only real criticism of the music appeared alongside further positive commentary in an article called "Why do Kids Dig Rock? And Why do their Parents Turn Off?" At the very least, this kind of conditioned approval suggests that reaction to youthculture could at times be far more nuanced than the absolute rejection implied by the generation-gap image. 
Further, if an aspect of that culture could reflect well upon the Canadian nation, it was seized upon. Reading articles in Maclean's Canadians did not see anything on most of rock music's key figures; artists ranging from Jimi Hendrix to Jefferson Airplane just did not appear outside the music review feature. Instead, artists like Ian and Sylvia, the Guess Who, and Gordon Lightfoot were featured; important not so much for their success but for the fact that they were Canadian successes. When one author listened to Ian and Sylvia play in New York his "chest swelled with patriotic pride." The possibility of Toronto becoming a center of music production was examined and while Canadian musician Leonard Cohen may have been incomprehensible, he was incomprehensible and famous." Similarly, while many criticized popular music as trite, the fact that Winnipeg's Guess Who played just that sort of music meant that "bubblegum (music) doesn't deserve the scorn that underground thinkers dump upon it." The journalist covering the Guess Who also seemed to take special delight in the fact that the band, whose success owed much to the song "American Woman" and its lyrics "we don't want your war machines, we don't want your ghetto scenes," was invited to play at the White House.

There was, of course, dissension; one author argued that the best way to Americanize oneself was to listen to Canadian music as it was indistinguishable from its southern counterpart. ${ }^{59}$ The fact remains, however, that the only American artist outside Bob Dylan to get any significant treatment by Maclean's was Tiny Tim. His "moist tendrils" and manner that "minces and swishes and twitters and flutters" were labeled a product of America's domestic situation which was equated with pre-Hitler days in Berlin. ${ }^{60}$ The late 1960 s were a period of increased nationalism and patriotic pride in Canada, fed by the centennial, the internal and international quagmire in the United States, and American political and economic 
interference in Canada. ${ }^{61}$ Thus, if it could contribute to national pride, even something as loud and annoying as rock music was endorsed in Maclean's.

Loosely attached to that overarching coalition of sex, drugs, and rock music in 1960s youth-culture was experimentation with Eastern religious movements, from Buddhism to Hare Krishnaism. Allen Ginsberg, a poet icon for both the beatnik generation and the baby-boomers, meditated on stage before his readings; German mystic author Herman Hesse was tremendously popular, ${ }^{62}$ and Theodore Roszak quoted poet Julian Beck who wanted "to zap them (the older generation) with holiness...to levitate them with joy...."63 All the same, the number of Canadian adherents to such movements was fairly small ${ }^{64}$ and that is, perhaps, an explanation for the minimal attention Maclean's paid to the subject.

Beyond bemused and clearly skeptical looks at astrology and Gestalt touch therapy, the most detailed look at Eastern philosophy came in an article entitled "The Beatles, the Maharishi, and Me." The title and the photo sequence of Mia Farrow, Donovan, and the Beatles really had little relevance to the article which was more intent on exploring the author's personal experience with meditation. That Maclean's chose to package the article as a feature on movie and rock stars reflects how little serious attention they gave the issue. The declining relevance of the church for Canadians, examined in books like Pierre Berton's The Comfortable Pew and other Maclean's articles like "Today's Religion: Is Anybody Listening?" and "Is God Obsolete?" likely meant that the younger generation's experimentation with different Gods and philosophies was more a novelty than a serious threat. ${ }^{66}$ Or perhaps once you have run one article on transcendental meditation, you have said about all that there is to say. Regardless of the motivation, the magazine certainly cannot be blamed for exaggerated or inflamed responses to spiritualism, and 
rather than harsh criticisms, the tone in the few articles that did appear was more amused than it was hostile.

If there was one institution that could be linked to Canadian youth in the 1960 s, it was the university. The major increase in university attendance, jumping from 141,388 in 1962 to 321,417 by 1972 , was not just a reflection of the baby-boom's huge numbers, it was also due to the fact that a greater percentage of young people were opting for post-secondary education. ${ }^{87}$ One of the most consistent and telling issues raised by Maclean's in its assessment of youth's university experience was its concern for the mental and physical welfare of students.

Beginning in 1961 with "The Anxious Years of an Undergraduate," there was an attempt to determine why some students were committing suicide, dropping out, or breaking down, and an effort was made to see what could be done about it. Despite one rebuttal from a professor who argued teachers should foster student stress, the concern with student well-being continued. "Student Crack-Ups" took an alarmed look at drop-out rates, deaths from pep-pills, the pressures of sex, grades, and an unfriendly campus; it even lamented the experience of one student forced to subsist on peanut-butter sandwiches. Similarly, in 1971 Barbara Frum argued that graduates facing paltry job prospects had actually been victimized by her own generation's lack of foresight and planning. ${ }^{68}$

This kind of anxious worry and guilt was clearly a carryover from the time those students were young children and their parents nervously consulted the guidelines of Dr. Spock and other psychologists to confirm whether or not they were raising their children properly. ${ }^{69}$ For many Canadian parents, their baby-boom children were their family's first generation ever to attend university, making the stress and turmoil of university life just as new and disconcerting for them as it was for their children. The prominent question of sending your child to university was 
thus "Are we doing the right thing?," the same concern raised twenty years earlier over potty-training and feeding times. This kind of concern was obvious in Maclean's and it suggests that the adoption of new attitudes and behaviors by youth did not bring any real change in the level of parental care and concern about their welfare.

To be a university student in the 1960 s by no means meant one was a left-wing radical. Preston Manning, founder of Canada's right-wing Reform Party, attended the University of Alberta in this decade. Similarly, in 1967 at the University of Waterloo, the student council's decision to extend aid to American draft-dodgers was repudiated by students despite an active publicity campaign by the council. $^{70}$ This contrasts sharply with the coverage of students found in Maclean's. With the exception of one article which characterized the majority of students as complacent," the impression given by the rest of the articles was quite clearly that university attendance entailed radicalism. If Maclean's was guilty of any of the charges levied against the media, it was guilty of exaggerating the extent of student radicalism.

To separate an examination of the young Canadian radicals who focused upon university issues like tuition and student participation from those who looked more broadly at society is to create a division that never really existed. The same people were involved in each struggle and the same ideas underlined both protests. The Student Union for Peace Action (SUPA), for instance, protested in favor of native rights and against Vietnam while at the same time arguing for more student involvement in university affairs. The philosophy forming the basis for all of these struggles was outlined in the 1962 Port Huron Statement of the American group Students for a Democratic Society. The manifesto called for "the establishment of a democracy of individual participation" and demanded "that the individual share in those social 
decisions determining the direction and quality of his life." This belief applied as much to university boards as it did to inner-city housing projects and it is thus only for the sake of ease rather than a reflection of reality that university-focused protest is being examined independently.

Radicals entering university in the 1960s found much to complain about. The Canadian Union of Students denounced the "master-slave" nature of post-secondary education in which privilege and input were reserved for professors and university governors. Tuition and other fees were denounced as elitist, and the solutions hastily implemented to deal with the unprecedented numbers of students entering university, from multiple-choice tests to teaching by television screen, were criticized as assemblyline education rather than enlightenment. Many opted to attend alternative "free-universities" like Toronto's Rochdale College and the wide Canadian circulation of the American essay "The Student as Nigger" neatly characterized both the ferocity and the extent of such feelings.

While Maclean's did not treat all of the problems which students saw, the magazine did give student criticisms a forum when it published a discussion between Canadian Union of Students activist Steven Langdon and a University of Toronto professor. Rather than the unequivocal dismissal of student protests that characterizes the idea of a generation-gap, Maclean's offered a limited and qualified sympathy.

The critic of the university had much to recommend him or her. A 1966 article on Simon Fraser University concludes by quoting the university's president Patrick McTaggert-Cowen who argued that the activist student "has ideas and he wants to be consulted. It's not that he wants to run the world...It's a fine thing I think." ${ }^{74}$ An editorial the following year urged universities to drop their patronizing attitudes towards students demanding a role 
in university affairs. The latter were "mature, able, and increasingly determined" and it was recommended that they be ceded a participatory role.

This sympathy for student participation did not, however, extend to many more of their demands. An end to tuition and fees was rejected on the basis that it would result only in the education of a meritocracy (which was strangely considered a problem) and education without structure was deemed unfeasible. ${ }^{76}$ Professors were to remain the teachers because they knew more than students and if universities allowed student power to extend any further than a representative voice, they would be heralding their own destruction. ${ }^{77}$ Maclean's clearly recognized the value of democracy, but only to a certain point. The atrocities committed by Germany's Nazi dictatorship just twenty years earlier had shown the dangers of quiescence among a populace and that probably does much to explain the endorsement of student participation and critiques. That acceptance, however, was limited by the fact that the foreseeable consequences of chaos and unrestricted equality were no better a reflection of the highly structured democratic models that had won the war. Maclean's could endorse a certain degree of protest, but when that protest foretold disorder, sympathy disappeared. Students could only go so far.

A similar view was offered of political radicalism; so long as it did not become too extreme, it won the magazine's sympathy. The most important precursor for the 1960s upheaval was the nuclear disarmament movement, represented in Canada by CUCND, the Combined Universities' Campaign for Nuclear Disarmament, and such groups clearly had Maclean's sympathy. The RCMP's alleged spying on such groups was flatly denounced and a lengthy article was devoted to American anti-nuclear activities. ${ }^{78}$ Just as stories on university students were heavily biased towards the 
radicals, in this latter article "pacifists", with their curious fasts, sit-ins and imprisonment won 25 paragraphs of the coverage. The more subdued activists were accorded only three, despite the fact that they were said to be growing faster and achieving more. The dramatic actions of a minority simply made better stories than the low-key exploits of the majority.

The New Left won some tremendously favorable coverage from Maclean's. The radicals who protested at La Macaza, one of two Bomarc missile bases in Canada, were portrayed as upstanding citizens. ${ }^{79}$ They were shown as polite, apologizing to police for the troubles they were causing; as stoic, enduring rain, heat, and blackflies; and as gutsy, repeatedly returning to the road after police had dragged them off. An editorial on the New Left suggested that if adults really probed their own values, they would determine that the only factor distinguishing them from youth was the fact that they cut their hair and bathed regularly. ${ }^{80}$ Likewise, after a few complaints about scraggly beards and their tendency to talk ad nauseum, a 1965 article on the activists stressed their willingness to act and their commitment to change. The investigation concluded with the summation, "I, for one, like it."

In such an analysis, Maclean's may well have been decidedly more liberal than Canadians in general. While these articles all give a very positive view of the Students Union for Peace Action, editorialists elsewhere pounced upon the existence of ties to SUPA as a key reason to deny funding to the government's youth project, the Company of Young Canadians. ${ }^{82}$ Similarly, while Maclean's quite harshly criticized the RCMP for treating American draft-dodgers as criminals and not as refugees, over half of Canadians polled in 1968 rejected the idea that Canada should accept dodgers as immigrants. ${ }^{83}$ This discrepancy is not particularly important. What matters more is the fact that the 500,000 Canadians buying 
Maclean's were presented with an interpretation of student radicalism that not only failed to take offense with the rejection of "Establishment Values," it frequently endorsed it. This suggests that the characterization of the media as inflammatory was not always accurate and furthermore shows that for some Canadians, the generation-gap was not as cavernous as the image suggests.

After the January 1969 riot at Sir George Williams University in Montreal where students caused over \$2 million in damage, there was an increasing focus upon the violence and upheaval of student protest. ${ }^{84}$ The chaos at Sir George Williams coincided with increasing brutality on American campuses. That same year Canadians saw students at Cornell University protesting not with placards but with rifles and artillery magazines. Bombings and arson became common on campus and four protesters were killed by the National Guard at Kent State in 1970. Canadians did not dismiss the events as an American problem. In 1969, the Committee of Presidents of the Universities of Ontario issued a draconian policy entitled "Order on the Campus" which argued that "the only response by which violence can be contained is the exercise of counterviolence." In retrospect, former University of Toronto President Claude Bissell has labeled the policy "an American document reflecting the shocked response to American campus violence."

Yet even after Canadian youth radicalism had clearly lost its non-violent innocence, it was not completely rejected by Maclean's. The only commentary on the Sir George Williams revolt was a criticism of those who denounced student radicalism as fascist; arguing that such a label was inappropriate for a cause as "real", "humane", and "generous" as that of the students. Furthermore, Maclean's argued that a tremendous strike against liberalism had been made by the administrators themselves with their failure to reinstate Perry Anderson, the professor 
exonerated of the charges of racism which had originally precipitated the riot. ${ }^{86}$ An editorial in June 1969 sharply criticized the protest over the awarding of a Canada Council grant to Marxist student protester Stanley Gray, labeling the backlash totalitarian and scarier than student unrest. The following month, readers were advised not to "scorn the kid with the sign" because his protests were supported by some of the foremost thinkers of the day. As will be shown in a moment, Maclean's treatment of radicalism was not consistently sympathetic, but it is important to take note of the fact that even after student protest became frightening, there was no rush to embrace the opposite side of the debate.

Maclean's had difficulty in tolerating extremism and hypocrisy. In a 1964 article, David Lewis Stein offered an alarmed interpretation of youth radicals' efforts to change the world. He argued that they felt the need for a social revolution (which by most accounts they did) and that the planned measures for change were "more extreme than anything previous generations of idealists ever dared contemplate." ${ }^{88}$ His article was by no means an endorsement. Maclean's also plainly rejected any attempt to equate the experience of Canada's natives with that endured by blacks in the U.S. As for the American revolutionaries ready to kill and die for change, nominating a pig for the U.S. presidency, and threatening to put LSD into the Chicago water supply, they were simply incomprehensible. In confronting hypocrisy, Maclean's questioned whether complaints about public injustice were particularly reasonable coming from those who engaged in individual sins, implying sex and drugs. The magazine was especially irritated at the movements' failure to condemn Soviet repression in Czechoslovakia and the Nigerian massacre in Biafra while it rattled on loudly about American evil.

When one considers the fact that student radicals were dismissing the very kind of comfortable, middle-class 
outlook that Maclean's embodied as "tired", "entrenched", and even "rotten to the core," the magazine's criticisms of the movement seem pretty mild. Maclean's eventually gave a regular forum to their self-labeled "token radical" Bob Bossin who used his article to interview a member of the Weathermen, the most violent and radical of the American student movements. He also complained of police brutality, authoritarian immigration officials, and the excitement of a successful campus sit-in. ${ }^{92}$ This could all be dismissed as a rather cynical effort at co-option, never really taken seriously because the very words "token radical" appeared beside the author's name. On the other hand, it is equally possible that Bossin's inclusion represented a real effort to foster understanding and it is just not what one would expect of an obstinate "Establishment" which dismissed radicalism as communism and which would do its best to silence rather than facilitate protests against the system.

One final aspect of Canadian youth radicalism, the Company of Young Canadians (CYC), remains to be considered. The CYC was the federal government's bold, if somewhat naive, attempt to capitalize on the enthusiasm and activism of the nation's youth. The paradoxical result was a government funded body whose principal aim was to attack the very status-quo that supported it. ${ }^{93}$ Many commentators in the Canadian press and politics did not respond favorably. The Moncton Times labeled it a "dangerous and disgusting growth"; Saturday Night criticized its "romanticism, opportunism, and organizational ineptitude"; 95 and the mayor of Calgary called for its disbanding on the basis that it was, "antidemocratic...preaching anarchy and chaos and using as a platform the unfortunate position of lower income people." 96

After some initial doubts about the feasibility of the CYC, Maclean's was consistently positive. The magazine 
dismissed criticisms about the organization being run by hippies as irrelevant, and argued that while the body was quite clearly an experiment, it was an experiment that was working. The magazine was even a little too optimistic, declaring the CYC "as vibrantly alive as ever" as late as 1971 when it was obvious that by 1969 it was suffering from divisive internal debate and from the association of its Quebec chapter with the terrorist FLQ. If anything, Maclean's dissent with the criticism of the organization shows that alliances were not clearly divided along generational lines.

The hippies, a catch-all label pasted on those young men and women who opted out of the confines of "mannered" society, be it with their long-hair, unkempt clothes, or their new vernacular, were not an especially welcome feature of daily life in the 1960s. In New York, large billboards appeared running slogans like "Keep America Clean: Take A Bath." The Canadian response was no more forgiving. A Boston Pizza outlet in Edmonton categorically refused to serve "long-hairs" and the principal of a Scarborough high school asserted that boys with long hair were "confused kids coming from confused homes whose parents have abrogated their responsibility." more telling is the fact that families took tours into hippie mainstays like Toronto's Yorkville Avenue to look at youth in much the same way that tourists at Disneyland take the jungle-boat cruise to stare at mechanical hippopotami and the natives in the bush.

Maclean's take on the hippie phenomenon was somewhat contradictory. Some authors joined in on the bashing while others found the responses directed at the hippies more reprehensible. All, however, concurred on the hippies' strangeness. Peter Gzowski's sympathetic look at the Mariposa Folk Festival was tempered by the fact that he was a little taken aback by the participants, concluding that, "it was no place for an adult." The 
first article devoted explicitly to hippies appeared in 1965 and used the word "nutty" repeatedly in its analysis. As they read quoted conversations like, "Oh, yeah, like I'm a square and you're all hip, like you're from the moon...", and learned of a giggle-ridden game of tiddly-winks, Canadian readers would have had a hard time disagreeing with the label. ${ }^{103}$ Later articles maintained the fascination, be it with plans to build a chocolate-marshmallow tank or the strange contents of posters hanging at Rochdale College. ${ }^{104}$ If the hippies were anything to this magazine, they were bizarre, giving some credence to the idea of a generation-gap.

At times, Canadians were offered criticism of the hippies. A July 1966 editorial argued that there ought to be a health law to force teenagers to wash regularly and a two-part article on hippies and the police resoundingly favored the latter. The author highlighted his trip to a hippie residence, stressing knee-deep garbage on the floor, the stench, the sound of rats, and the virtual kidnaping of a naive fifteen year-old girl into a hippie "marriage" replete with sex and drugs. ${ }^{105}$ Because Maclean's did not define exactly what a hippie was, Canadians may well have pictured these scenarios as the fate of any youth whose hair had grown just a little too long. If readers wanted an ally in their commiseration or some further ammunition for their disgust, Maclean's provided it.

More measured criticism appeared in articles on Toronto's Rochdale College and the Toronto Peace Festival. Although dealing with quite different subjects, both reached the conclusion that reality had a way of souring idealistic dreams. ${ }^{106}$ Rochdale College, North America's largest experiment in co-operative housing and education, had the rather infamous distinction of being Canada's largest drug dispensary, and not without reason. In the first four months of 1973 , police seized 54 pounds of marijuana, 8,646 grams of hashish, 32 grams of hashish 
oil, 85 grams of opium, 188 grams of MDA, 974 tabs of LSD, 370 caps of THC, 8 grams of cocaine, and 103 caps of mescaline. ${ }^{107}$ Maclean's, however, criticized the sex and drugs oriented criticism that Rochdale had received in the press. The college represented a clear opportunity for sensationalism but that was not capitalized upon. Instead, the article challenged the philosophical integrity of hippiedom. Many of the students who flocked to Rochdale had believed in total freedom yet once their complex began to be inundated by outside hippies, they spoke not only of restoring all the locks but of adding video-monitoring as well! Similarly, before the existence of Rochdale, it was easy to attribute one's lack of poetic, philosophical, or artistic brilliance to stunting by "the system," but once that repression was removed and genius still did not flower, the consequence was disillusionment. The fundamentals of the movement were found to be wanting.

When Maclean's looked at the attempts to organize the Toronto Peace Festival, a large outdoor concert, the "Karma Foundation" responsible for the planning was portrayed as more greedy and bureaucratic than its name and project suggested. Worse, the author noted that the peaceful philosophy of the "love generation" was rapidly being superseded by a new atmosphere where the "music is heavier, the drugs are harder, and the colors faded." Both articles were essentially lamenting the fact that something great could have been accomplished but sadly was not. These were not the triumphant victory cries of one enemy over a rival; instead these criticisms showed a sympathy for ideals that just did not translate into reality.

The hippies did not escape unscathed in Maclean's, but neither did their opponents. The hippies may have been strange, but the residents of Orillia, where the Mariposa Folk Festival was held, were simply hypocritical given their open hostility to the audience juxtaposed against their ready acceptance of the festival's money. ${ }^{109}$ Vancouver was the 
object of even harsher criticism. Its police, by giving undue and authoritarian attention to harmless teenagers, were creating a menace where none existed and were consequently overlooking the city's troubling rates of suicide, heroin addiction, and rioting. Its landlords were criticized for humiliating altruistic Diggers and for denying the anti-poverty activists any place to live. Similarly, the Vancouver Sun came under attack, not only for refusing to run articles sympathetic to hippies but also for the inflammatory nature of articles like "Lice on long-haired hippies? Man, that's just lousy." pro-police author mentioned earlier conceded that the arrest of hippies for loitering in front of Vancouver's centennial fountain was unfair given the failure to similarly arrest the little old ladies and clean-cut students lingering alongside them. ${ }^{111}$ Finally, just as occurred with rock music, when the hippies were able to provide one-upmanship on the U.S., all reservations disappeared. This clearly occurred in a piece on a Toronto production of the musical "Hair" with the article's gleefully patriotic note that the New York Times had labeled the Canadian troupe the "hairiest" of all. ${ }^{112}$ If this had not somehow provided a victory over the Americans, such a statement would have been a dubious compliment at best.

Maclean's undoubtedly missed a lot. There was never any real probing beyond the surface of hippie appearance and activities to try to assess the philosophy of why hippies acted and looked the way they did. The hippies in Maclean's were not Theodore Roszak's counterculturalists, taking moral action against an evil society, nor were they Jerry Rubin's vehement drop-outs calling for the downfall of "Amerikkka" and wearing their longhair as an equivalent of black skin. ${ }^{113}$ Instead, these were silly kids who smoked marijuana, wrote nonsense poems, and smelled badly. That said, Maclean's was not hysterically analyzing hippies in every issue and its 
judgments were by no means consistent, let alone systematically hostile. In this, the blame levied against the media for its overexposure of the phenomenon and for its rush to emphasize the negative just does not apply to this magazine. If anything, what can be seen by looking at the articles is that the anecdotes on billboards and the anger of high-school principals, the very things that compose the image of the chasm between old and young, by no means represented a consensus of opinion among adult Canadians in the 1960s. The idea of a generation-gap is an image, and like all images, while it feeds off reality, it does not necessarily reflect it.

Being young in the 1960 s by no means meant one was a hippie or a radical. To its credit, Maclean's did examine youth who fit neither characterization, but in the end, the average just did not make for a good story. In Maclean's, if a youth was neither a hippie nor a radical, he or she could be a teeny-bopper: a teenager interested only in fashion, dating, and the latest popular music trend. This kind of image was fairly infrequent, appearing mostly in fashion pages ${ }^{114}$ and oncelin an interview with the host of a Canadian TV-show whose squeaky-clean image, right down to the Varsity quarterback boyfriend, won her the label "Miss Teenager of Canada." Another article looked at teenagers and cars, not at the hippies who covered them with psychedelic designs as a rejection of middle-class values, but at those who saw cars as a "status symbol, date bait, and escape" ${ }^{\text {"116 }}$ and there was also a consideration of the difficulties youth faced in staying abreast of the latest trends.

Alternatively, a teenager could be brilliant. A group of teenagers devoted to classical music was labeled, "the most reassuring adolescent phenomenon since long before the Beatles" and numerous university students had the opportunity to express their opinions. Among those students, by far the most attention was given to 
valedictorians. In 1969, Canada's five brightest high-school graduates (two of whom could not grow their hair long because their mothers forbade it) were featured and in 1971 the same was done of six top university graduates.

While such characterizations left the mass of average university students more or less neglected, a far more serious omission was the failure to treat the thousands and thousands of young people who did not attend university at all. In 1971, Canada's population of 20 to 24 year-olds was $1,889,400$ while the total university enrollment in 1970-1971 was 309,469. ${ }^{120}$ As for what the majority in that age group was doing, Canadians found no answer in Maclean's. If one considers that hippies and radicals were a minority on campus and then remembers that those on campus were themselves a minority of the youth population, the coverage of these figures appears fairly incongruent with what was actually happening in Canada. Maclean's quite clearly ignored the quiet, boring majority.

"Generation-gap" was not a phrase coined in retrospect, it was a label created and discussed during the 1960s. Sociologists conducted studies to assess its validity, political radicals based their arguments around it, and rock bands like the Who sang about it. Maclean's, however, devoted only anecdotal attention to the issue. The words "generation-gap" appeared occasionally ${ }^{121}$ but an article focusing on the conflict between teenagers and parents never appeared. This failure to treat the gap is fitting because in the pages of Maclean's no such chasm existed. While drugs were unquestionably wrong, judgements on all other aspects of youth and youth culture were more nuanced. Hippies, radicals, their music and their sex lives were never fully endorsed, but neither were they unilaterally rejected.

Images and popular recollections have to be treated with caution. In characterizing adult-youth relationships 
during the 1960s, "generation-gap" is the catch-phrase, but looking at Maclean's shows it to be a simplification. There were major differences in outlook and opinion between old and young, but the half-million Canadians reading this magazine were seeing a marked degree of endorsement and sympathy towards the younger generation, its views, and its actions. At times the treatment was skewed, at times it was inflammatory, but it was not the kind of systematic hostility found enshrined in the period's mythology.

\section{NOTES}

' Rex Weiner and Deane Stillman, Woodstock Census: The Nationwide Survey of the Sixties Generation (New York: The Viking Press, 1979), 40.

${ }^{2}$ Doug Owram, Born at the Right Time: A History of the BabyBoom Generation (Toronto: University of Toronto Press, 1996), xxi.

${ }^{3}$ Ibid., ix-x.

${ }^{4}$ William L. O'Neill, American High: The Years of Confidence, 1945-1960 (New York: The Free Press, 1986), 35.

${ }^{5}$ For an example of repeated references to the generation-gap in a popular recollection of the 1960s, see Alan Edmonds, Canada's Illustrated Heritage: The Years of Protest, 1960/1970 (Toronto: Natural Science of Canada, 1979).

${ }^{6}$ Theodore Roszak, The Making of a Counter Culture (New York: Doubleday, 1968), 3.

${ }^{7}$ Weiner and Stillman, Woodstock Census, 187.

${ }^{8}$ Michael E. Brown, "The Condemnation and Persecution of Hippies," in Edgar Z. Friedenberg, ed. The Anti-American Generation (United States: Transaction, 1971), 114.

${ }^{9}$ Ulrich 's International Periodicals Directory (New York: Bowker, 1963), 232; Canada Year Book, 1963-64, 156.

${ }^{10}$ For a summary of Spiro Agnew's complaints see Martin H. Seiden, Who Controls the Mass Media? Popular Myths and Economic Realities (New York: Basic Books, 1974), 64-66.

" Fraser Sutherland, The Monthly Epic: A History of Canadian Magazines, 1978-1989 (Markham: Fitzhenry and Whiteside, 1989), 6. 
12 Mary Vipond, The Mass Media in Canada (Toronto: James Lorimer, 1989), 72.

${ }^{13}$ Sutherland, The Monthly Epic, 237.

${ }^{14}$ Ulrich 's, 232. Chatelaine had a circulation of 750,000 and Liberty 610,000 .

${ }^{15}$ Sutherland, The Monthly Epic, 242.

${ }^{16}$ For example, Peter Gzowski was born in 1934 and Barbara Frum in 1937.

${ }^{17}$ Beth L. Bailey, From Front Porch to Back Seat (Baltimore: John Hopkins University Press, 1988), 141.

${ }^{18}$ Simma Holt, Sex and the Teenage Revolution (Toronto: McClelland and Stewart, 1967), 153.

19 "Hypocrisy in the Criminal Code: Preventing Conception is an Offense," Maclean's 21 March 1964, 4.

${ }^{20}$ Douglas Marshal, "The Revolution Begins,"Maclean's, March 1967, 20. See also Ian Sclanders, "The Birth Control Explosion," Maclean's, 21 March 1964, 16, for equally optimistic claims.

${ }^{21}$ Eric Hutton, "The Case For- and Against- The Pill," Maclean's, 22 August 1964, 12; Marshal, "The Revolution Begins,"20.

22 Alexander Ross, "Meet your Friendly Local Abortionist," Maclean's, May 1968, 30.

${ }^{23}$ Canadian Institute of Public Opinion, The Gallup Poll of Canada, 8 September 1965 reported 67 per cent of Canadians stating birth control was not morally wrong, up from 55 per cent in 1961 . The poll taken 30 December 1972 had 67 per cent supporting availability of information and access to birth control for teenagers. Between the poll taken on 23 April 1969 and the poll taken 3 January 1973 the majority moved from accepting mental health as a justification to arguing that abortion should be a choice between a woman and her doctor alone.

${ }^{24}$ Angus McLaren and Arlene Tigar McLaren, The Bedroom and the State (Toronto: McClelland and Stewart, 1986), 134.

${ }^{25}$ Canadian Institute of Public Opinion, The Gallup Poll of Canada, 11 April 1970, 57 per cent stated pre-marital sex was morally wrong. ${ }^{26}$ Sidney Katz, "Going Steady: Is it Ruining our Teen-Agers?," Maclean's, 3 January 1959, 9-10.

${ }^{27}$ Mordecai Richler, "Making It With the Chicks," Maclean's 8 October 1960, 30.

${ }^{28}$ Pierre Berton, "It's Time We Stopped Hoaxing our Kids about Sex," Maclean's, 18 May 1963, 66; "Mailbag," Maclean's, 6 July 1963, 7; Sutherland, The Monthly Epic, 235.

${ }^{29}$ E.W. Harrison, "The New Morality," Maclean's, 15 October 1966, 60; Robert Thomas Allen, "The New Moralists," Maclean's, 15 
October 1966, 2; Elizabeth Brodie, "The Dangers of the New Promiscuity," Maclean 's, August 1971, 14.

${ }^{30}$ Owram, Born at the Right Time, 256-57.

${ }^{31}$ Weiner and Stillman, Woodstock Census, 166.

${ }^{32}$ Sandra Peredo, "A Little Girl in a Big, Big Town," Maclean's, 3 September 1966, 10; Bonnie Buxton, "The Unchaperoned Girl's Guide to Europe," Maclean's, June 1967, 30; Arnaud Maggs and John Zichmanis, "Seasons of Love," Maclean's, December 1967, 22; Adrienne Clarkson, "Three Men From Three Generations Talk...," Maclean's, June 1971, 27; Marjorie Harris, "Back to the Virginal Look for Spring," Maclean's, May 1968, 32; Harris, "The New Modesty," Maclean's, January 1970, 31.

${ }_{33}$ Weiner and Stillman, Woodstock Census, 199.

${ }^{34}$ Timothy Miller, The Hippies and American Values (Knoxville, University of Tennessee Press, 1991), 61. The candidate's campaign slogan was, "What have I got to hide?"

${ }_{35}$ Timothy Miller, The Hippies and American Values (Knoxville, University of Tennessee Press, 1991), 55.

${ }^{36}$ Kenneth Westhues, Society's Shadow: Studies in the Sociology of Countercultures (Toronto: McGraw-Hill Ryerson, 1972), 1.

${ }^{37}$ Canada Year Book, 1965, 413, and 1975, 56.

${ }^{38}$ Westhues, Society's Shadow, 3; Brown, "Condemnation and Persecution of Hippies," 117; Canadian Institute of Public Opinion, The Gallup Poll of Canada, 24 July 1971.

39 "Fighting Teenage Drug Habit," Maclean's, 20 June 1959, 1; Cathy Breslin, "Why We're Finally Outlawing 'Goofballs," Maclean's, 15 July 1961, 14.

${ }^{40}$ David Lewis Stein, "The Growing Acceptability of 'Harmless' Narcotic," and "How I Worked My Way Through College Peddling Pot," Maclean's, 4 January 1964, 14, 15, 44.

${ }^{41}$ Jon Ruddy, "Some of the Best People Smoke Pot," Maclean's, January 1969, 35; M.L. Chazottes, “A Frightening New Theory of the Perils of Pot," Maclean's, October 1970, 66; Gene Lees, "Keep off the Grass," Maclean 's, July 1973, 4.

${ }^{42}$ Westhues, Society's Shadow, 1; Counter Culture icons Timothy Leary and Allen Ginsberg both denounced hard drugs, see Miller, The Hippies and American Values, 44.

${ }^{43}$ Robert Fulford, "All the Facts," Saturday Night, October 1971, 10; Fulford, "Drugs as Semi-Crime," Saturday Night, July 1970, 10; Fulford, "The Hard Truth behind the Marijuana Laws," Saturday Night, May 1969, 12.

${ }^{44}$ Peter Gzowski, "My Five Marijuana Problems," Saturday Night, November 1970, 23; also, Michael Popovich, "Never Trust a Junkie," 
Saturday Night, March 1973, 21.

${ }^{45}$ Weiner and Stillman, Woodstock Census, 106.

46 "The Uncanny Art of 27 Drugged Painters," Maclean's, 16 December 1961, 22.

${ }^{47}$ Sidney Katz, "The Heaven or Hell Drugs," Maclean 's, 20 June $1964,9$.

${ }^{48}$ Pam Hyatt Poster, "How LSD Saved My Marriage," Maclean 's, 5 November 1966, 10; William Nicolls, "Model Mystics with LSD," Saturday Night, June 1966, 42.

49 June Callwood, "How Bad is the Young Drug Scene?," Chatelaine, August 1969, 60.

${ }^{50}$ Sidney Katz, "How Can I Tell if my Child is on Drugs?," Maclean's, November 1968, 62; M.L. Chazottes, "How Can You Tell if your Child is on Drugs?," Maclean's, August 1970, 61.

${ }^{51}$ Douglas Marshall, "Bill Clement: He Bridges the Generation Gap," Maclean's, July 1969, 42; Tom Buston, "View from the U.S. of A.," Maclean's, August 1971, 6.

${ }^{52}$ Miller, The Hippies and American Values, 35 and 41.

${ }^{53}$ Canada Year Book, 1973, 212. The population of 15- to 19-yearolds was 2,114,345.

${ }^{54}$ Allan Fotheringham, "The Beatle Menace," Maclean's, 19 September 1964, 1.

s5 Weiner and Stillman, Woodstock Census, 70.

${ }^{56}$ Peter Gzowski, "Dylan: An Explosion of Poetry," Maclean's, 22 January 1966, 20, 40; Larry Coryell and Moe Koffman, "Why do Kids Dig Rock? And Why do their Parents Turn Off?," Maclean's, December 1969, 47.

57 Jack Batten, “The Sweet Song of Success," Maclean 's, 21 August 1965, 13; Jon Ruddy, "Is the World (or Anybody) Ready for Leonard Cohen?" Maclean's, 1 October 1966, 18.

s8 Batten, "The Guess Who," Maclean's, June 1971, 28. Ironically, the Guess Who were not pleased by the characterization and actually filed a libel suit against Batten. See, Batten, "Confessions of a Retired Rock Critic," Saturday Night, March 1973, 18.

${ }^{59}$ Jon Ruddy, "How to Become an American Without Really Trying," Maclean's, November 1969, 61.

${ }^{60}$ Alexander Ross, "Tiny Tim-God Bless Him!" Maclean's, November 1968, 45.

${ }^{61}$ Robert Bothwell, et al, Canada since 1945 (Toronto: University of Toronto Press, 1989), 307.

${ }^{62}$ Weiner and Stillman, Woodstock Census, 52.

${ }^{63}$ Roszak, The Making of a Counter Culture, 152.

${ }^{64}$ Owram, Born at the Right Time, 209. ${ }^{65}$ Jon Ruddy, "Okay, 
Everybody, Get Ready for The Age of Aquarius," Maclean's, February 1970, 28; on Gestalt therapy, Nancy MacNeill, "These Feet were Made for Loving, and Hating, and Feeling in the New Togetherness," Maclean's, September 1970, 38; Paul Saltzman, "The Beatles, the Maharashi, and Me," Maclean's, June 1968, 26.

${ }^{66}$ Bordon Spears, "Today's Religion: Is Anybody Listening?" Maclean 's, 14 December 1964, 21; "Is God Obsolete?," Maclean 's, 6 August 1966, 7.

${ }^{67}$ Canada year Book, 1963, 344, and 1974, 295; Owram, Born at the Right Time, 179.

${ }^{68}$ Barbara Moon and David Lewis Stein, "The Anxious Years of an Undergraduate," Maclean's, 21 October 1961, 13; C.F.J. Whebell, “Argument," Maclean's, 16 October 1965, 70; Ben Rose, "New Specter on the Campus: Student Crackups," Maclean's, 15 December 1965; Barbara Frum, "Class of '71," Maclean's, June 1971, 19. ${ }^{69}$ Owram, Born at the Right Time, 48-49.

${ }^{70}$ Gary Moffatt, A History of the Peace Movement in Canada (Ottawa: Grapevine Press, n.d.), 47. See also Helen Lefkowitz, Campus Life: Undergraduate Cultures from the End of the Eighteenth Century to the Present (Chicago: Chicago University Press, 1987), 234. Horowitz notes that in 1969 , the highest point of the protest movement, only 28 per cent of American college students had taken part in any demonstration during the last four years.

71 Douglas Marshall, “Campus '67," Maclean's, November 1967, 11.

${ }^{72}$ Moffatt, A History of the Peace Movement in Canada, 41.

${ }^{73}$ Kenneth Westhues, "Inter-Generational Conflict in the 1960s," in Prophecy and Protest: Social Movements in Twentieth-Century Canada, in Samuel D. Clark, et al, eds., (Toronto: Gage Educational Publishing, 1975), 390; Kostash, Long Way From Home, 77; Patricia Jansen, "In Pursuit of Human Values: The Student Critique of the Arts Curriculum in the 1960s," in Paul Axelrod and John Reid, Youth, University, and Canadian Society (Montreal: McGill-Queen's University Press, 1989), 250.

${ }^{74}$ Jon Ruddy, "The Knowledge Explosion," Maclean 's, 4 June 1966, 8.

75 "Stop Treating College Students like Children," Maclean's, November 1967, 4.

76 "Why University Students Should Go On Paying Fees," Maclean 's, 1 December 1965, 4.

77 "Give Students a Voice-But Let's Not Let Student Power Spell Destruction," Maclean's, November 1968, 4.

78 "Are we really recruiting youngsters to spy on each other?" 
Maclean 's, 15 July 1961, 2; Ian Sclanders, "Peace Gets a Friendlier hearing in the USA," Maclean's, 11 August 1962, 9.

${ }^{79}$ David Lewis Stein, "The Peaceniks go to La Macaza," Maclean's, 8 August 1964, 10.

80 "A Time to 'Dig' our Values?," Maclean's, 15 November 1965, 14.

${ }^{81}$ Peter Gzowski, "The Righteous Crusaders of the New Left," Maclean's, 15 November 1965, 42.

${ }^{82}$ Margaret Daly, The Revolution Game (Toronto: New Press, 1970), 36.

83 "Dear RCMP: Draft Dodgers are Refugees, not Criminals," Maclean 's, 17 September 1966, 4; Canadian Institute of Public Opinion, The Gallup Poll of Canada, 27 November 1968. Fifty-one percent opposed, only 28 per cent in favor.

${ }^{84}$ Owram, Born at the Right Time, 289.

${ }^{85}$ Claude Bissell, Halfway Up Parnassus (Toronto: University of Toronto Press, 1974), 143.

86 "Do You Remember Perry Anderson? You Should," Maclean's, November 1969, 8.

87 "The Disturbing Backlash from the Campus Revolt," Maclean's, June 1969, 7: "Don't Scom the Kid with the Sign; He's in Good Company," Maclean's, 17 April 1965, 4.

${ }^{88}$ David Lewis Stein, "The Younger Generation," Maclean's, 20 June 1964, 1.

89 "We have Bigotry All Right-But No Alabamas," Maclean's, 17 April 1965, 4; Gordon Donaldson, "Who's Who Among Hippies, Yippies and Sundry other Troublemakers," Maclean's, November $1968,1$.

90 "Rebels in Glass Houses Shouldn't Throw Stones," Maclean's, 5 November 1966, 4; "A Strange Inexplicable Silence From the New Left," Maclean's, September 1968, 4.

${ }^{91}$ Miller, The Hippies and American Values, 7.

${ }^{92}$ For Weathermen member interview and police brutality, see "Cops, Karate, Hate, Love, Revolution, and All Like That," Maclean's, March 1970, 28; for immigration, "Stop That Man! He's Smuggling an Orange," Maclean's, February 1970, 14; for sit-in, "My First Real Honest-to-God Big-Time Campus Sit-In. We Win!," Maclean's, June 1970, 22.

${ }^{93}$ Owram, Born at the Right Time, 222-25.

94 Alexander Ross and Michael Valpy, "CYC's Young rebels," Maclean's, August 1967, 26.

95 James Littleton, "The CYC, the New Left, and the Improved Plastic Mousetrap," Saturday Night, November 1969, 31. 
${ }^{96}$ Daly, The Revolution Game, 79.

97 "So the CYC's run by hippies? It's OK with us," Maclean 's, August 1967, 4; Ross and Valpy, "CYC's Young rebels,"26.

${ }^{98}$ Steven Langdon, "The View from Ottawa," Maclean's, November 1971, 6; Owram, Born at the Right Time, 298.

${ }^{99}$ Brown, "The Condemnation and Persecution of Hippies," 100.

${ }^{100}$ Gordon Turtle, ed., Dear Editor: Selected Letters to the Gateway, 1908-1982 (Edmonton: University of Alberta Students' Union, 1982), 48; Jon Ruddy, "Where Did You Go? School! What Did You Learn? 'DON'T!',' Maclean's, 19 November 1966, 57.

${ }^{101}$ Owram, Born at the Right Time, 211.

${ }^{102}$ Peter Gzowski, "Where The Boys and Girls Go," Maclean's, 21 September 1963, 19.

${ }^{103}$ Jon Ruddy, "Stop the World-They Want to Get Off," Maclean's, 1 November 1965, 20.

${ }^{104}$ Douglas Marshall, "We Just Want To Do Our Thing," Maclean's, July 1968, 20; Alan Edmonds, "The New Learning: Today it's Chaos-Tomorrow...Freedom?” Maclean's, May 1969, 77.

105 “OK, be a Beatnik - but for Heaven's Sake Wash," Maclean's, 2 July 1966, 4; Douglas Marshall, "Okay, Let Them Do Their Thing, But Not On My Lawn,"Maclean 's, July 1968, 64.

${ }^{106}$ Edmonds, "The New Learning," 77; Bob Bossin, "The Ups and Downs of a Great Canadian Peace Festival," Maclean's, July 1970, 48.

${ }^{107}$ David Sharpe, Rochdale: The Runaway College (Toronto: Anansi, 1987, 1987), 11, 244.

${ }^{108}$ Bossin, "The Ups and Downs," 53.

${ }^{109}$ Gzowski, "Where the Boys and Girls Go," 21.

${ }^{110}$ Jack Batten, "Vancouver: How the Town's Fighting the Dread Hippie Menace," Maclean's, August 1967, 18.

"II' Marshall, "We Just Want," 60.

112 Kaspars Dzeguze, "What 'Hair' is Doing to a Bunch of Otherwise Ordinary Canadian Kids...," Maclean's, April 1970, 18.

${ }^{113}$ Jerry Rubin, Do It: Scenarios of the Revolution (New York: Simon and Schuster, 1970), 94.

114 Jack Batten, "Hawks, Chicks, and a Swinging Nest," Maclean 's, 20 March 1965, 23; Marjorie Harris, "The Look," Maclean's, 20 August 1966, 10.

115 Penny Williams, "The Ultimate T.V. Teenager," Maclean's, 2 May 1966, 17.

${ }^{116}$ Sidney Katz, "A Candid New Report on the Teenager and the car," Maclean's, 2 December 1964, 9.

${ }^{117}$ Shirley Mair, “Argument," Maclean's, 1 May 1965, 68. 
118 Alexander Ross, "New Rival for the Beatles: Beethoven," Maclean's, 20 February 1965, 45.

119 Alan Edmonds, "These Shall Inherit the Earth," Maclean's, December 1969, 66; Barbara Frum, "The Valedictorians," Maclean's, June 1971, 22.

${ }^{120}$ Canada Year Book, 1973, (population) 212, (university) 330.

${ }^{121}$ Marshall, "Bill Clement," 42 or "Don't Call Me Pig, You LongHaired Punk," Maclean's, October 1969, 7. 